\title{
Oil Contamination in Ogoniland, Niger Delta
}

\author{
Olof Lindén, Jonas Pålsson
}

Received: 13 July 2012/Revised: 19 November 2012/Accepted: 29 April 2013/Published online: 8 June 2013

\begin{abstract}
The study shows extensive oil contamination of rivers, creeks, and ground waters in Ogoniland, Nigeria. The levels found in the more contaminated sites are high enough to cause severe impacts on the ecosystem and human health: extractable petroleum hydrocarbons (EPHs) (>10-C40) in surface waters up to $7420 \mu \mathrm{g} \mathrm{L}{ }^{-1}$, drinking water wells show up to $42200 \mu \mathrm{g} \mathrm{L}^{-1}$, and benzene up to $9000 \mu \mathrm{g} \mathrm{L}^{-1}$, more than 900 times the WHO guidelines. EPH concentrations in sediments were up to $17900 \mathrm{mg} \mathrm{kg}^{-1}$. Polycyclic aromatic hydrocarbons concentrations reached $8.0 \mathrm{mg} \mathrm{kg}^{-1}$, in the most contaminated sites. The contamination has killed large areas of mangroves. Although the natural conditions for degradation of petroleum hydrocarbons are favorable with high temperatures and relatively high rainfall, the recovery of contaminated areas is prevented due to the chronic character of the contamination. Oil spills of varying magnitude originates from facilities and pipelines; leaks from aging, dilapidated, and abandoned infrastructure; and from spills during transport and artisanal refining of stolen oil under very primitive conditions.
\end{abstract}

Keywords Nigeria $\cdot$ Niger Delta $\cdot$ Ogoniland · Oil spill $\cdot$ Pollution $\cdot$ Mangrove

\section{INTRODUCTION}

Oil contamination originating from anthropogenic activities such as drilling operations and transportation is a wellknown and well-studied environmental pollution problem. However, due to their visibility and dramatic appearance,

Electronic supplementary material The online version of this article (doi:10.1007/s13280-013-0412-8) contains supplementary material, which is available to authorized users. oil spills still attract the attention of the media and consequently the public and politicians, as in the case of the Deepwater Horizon blowout in the Gulf of Mexico in 2010. However, the oil spills occurring in the Niger Delta have received less attention in global media, despite significantly higher impacts on human health and the local ecology (UNEP 2011).

Oil spills mainly impact vegetation and wildlife, such as seabirds. Most of the impacts are due to the physical characteristics of the oil. The adhesive properties lead to reduced mobility and dissolution of natural fats and waxes on body surfaces, feathers etc. (NRC 2003; ITOPF 2011a). Certain aromatic petroleum hydrocarbons may also cause direct toxic impacts due to ingestion or penetration through body surfaces such as gills (Middleditch 1984; Jenssen 1996; Heubeck et al. 2003). Many of the toxic as well as non-toxic hydrocarbons evaporate and are degraded by microorganisms quite rapidly (NRC 2003; ITOPF 2011b). However, there may be adverse long-term effects under particular conditions (Peterson et al. 2003). An estimated 2 million tons of oil is released into the environment annually from human and natural processes (NRC 2003). About half of this comes from natural seepage of oil into the sea and coastal environments from oil deposits on the continental shelf (NRC 2003).

Once oil has contaminated wetlands such as marshes and mangroves, it is often very difficult to remove without causing further damage to these environments (NOAA 1994, 2002; NRC 2003; Chan and Baba 2009). Oil slicks may enter such areas during high tide and as the tide recedes, oil is deposited on the vegetation causing asphyxiation of the plants. Toxic effects may also occur if the oil is fresh and contain a high amount of light aromatic hydrocarbons. Obviously, if the mangrove vegetation dies, many plants and animals associated with this ecosystem 
will also suffer due to the keystone character of the mangrove vegetation.

The Niger River has a total length of about $4100 \mathrm{~km}$ and is the third longest river in Africa. The Niger River basin covers a drainage area of 2.3 million $\mathrm{km}^{2}$, about $7.5 \%$ of the African continental landmass. The river starts in the Guinea Highlands and flows through Mali and Niger on its way to Nigeria. The average annual discharge from the Niger River into the Gulf of Guinea is $177 \mathrm{~km}^{3}$ (Frenken 1997). The Delta stretches from the Benin River in the west to the Bonny River in the east. It is a vast flood plain built up by the accumulated sediments washed down the Niger and Benue Rivers. The mangrove and freshwater swamp forest of the Niger Delta is the largest in Africa, and the third largest in the world, covering some $70000 \mathrm{~km}^{2}$. However, in many places, the forests have been extensively logged and agriculture has encroached into the wetland (Moffat and Linden 1995; Mmom and Arokoyu 2010). Most of the lowland rainforests that used to characterize the areas landward from the swamp forests are now derived savannah or agricultural land with only small areas of more or less degraded coastal rainforest left. The high rainfall and river discharge during the rainy season combined with the low, flat terrain, and poorly drained soils cause frequent and widespread flooding and erosion. Often over $80 \%$ of the delta is affected by seasonal floods stretching from the Benin River in the west to Bonny River in the east (Moffat and Linden 1995). The tidal range at Port Harcourt is on average $1.8 \mathrm{~m}$.

Nigeria has Africa's largest reserves of oil and gas within its borders and most of these resources exist in the Niger Delta and on the continental shelf of the country. Oil extraction in the Niger Delta has been going on since the 1950s and Nigeria exports around 15 million tonnes of oil every day, ranking one of the top 15 exporters in 2009 (CIA 2012). The reserve of crude oil in Nigeria is estimated to be 270 billion tonnes, making it one of the top 10 largest reserves in the world in 2011 (CIA 2012). Oil exports accounts for $95 \%$ of the foreign exchange earnings and $80 \%$ of the budgetary revenues. The quality of the extracted oil is considered good, as it has low content of sulfur $(0.14 \%)$ and a high content of lighter fractions (EIR 2005).

Oil spills have occurred repeatedly for decades in the Niger Delta and large parts of the land and wetlands are chronically affected by oil spills. Due to the influence of the tides and at times floods in connection with rains, spilt oil is rapidly distributed over large areas and remobilized with rising tides. The oil originates from leaking pipelines, wellheads, and flow stations; from spills in connection with transport of mostly stolen oil; from illegal tapping of the wells; and from artisanal refining under very primitive conditions. As a result of the contamination of oil in mangroves and wetlands as well as on land, oil has
Fig. 1 Map of Ogoniland, showing the four Local Government Areas (LGA's), the pipelines and the sampling sites. NNPC Nigerian National Petroleum Company, SPDC Shell Petroleum Development Company (Nigeria) Ltd. Samples were collected during the period April-November 2010. For exact site location coordinates see Electronic Supplementary Material

penetrated into soils down to several meters and has contaminated ground waters over large areas. This has resulted in the contamination of water wells as a particularly serious concern from a human health perspective (Moffat and Linden 1995; Ana et al. 2009; Mmom and Arokoyu 2010; UNEP 2011).

The Niger Delta has been the scene of a long series of conflicts, two of the most serious being the Biafra War in 1967-1970, and the Ogoni Uprising in the 1990s. The violence has been centered around the cities of Warri in Delta State and Port Harcourt in Rivers State (Human Rights Watch 2005; Idemudia 2009; UNEP 2011). As a result of these conflicts, oil companies for decades found it difficult to carry out oil production in parts of the Niger Delta. One such area is Ogoniland, immediately east of Port Harcourt (Fig. 1). This area consists of four local government areas (LGAs): Eleme, Tai, Gokana, and Khana with a total population of 830000 (UNEP 2011).

During 2009-2011, at the request of the Federal Government of Nigeria, the United Nations Environment Programme (UNEP) carried out a survey of the nature and extent of oil pollution in Ogoniland. The assessment covered contaminated land, ground and surface water, sediments, vegetation, air pollution, public health, industry practices, and institutional issues. The assessments were made in collaboration with a number of partners in the region including experts from Rivers State University of Science and Technology, Nigerian Government, agencies at national, state, and local government levels, traditional rulers, and various community groups. An additional objective was to determine appropriate remediation measures to rehabilitate contaminated sites to the level of international standards. The full report including the results from all the assessments and the recommendations regarding rehabilitation and remediation was published in 2011 (UNEP 2011). The results presented in this report were collected as a part of the UNEP assessment and focus on the petroleum hydrocarbon contamination of surface waters, drinking water from wells, sediment, and biota.

\section{MATERIALS AND METHODS}

\section{Sampling}

The sampling strategy was developed in collaboration with local experts from the Fisheries and Aquatic Environment 


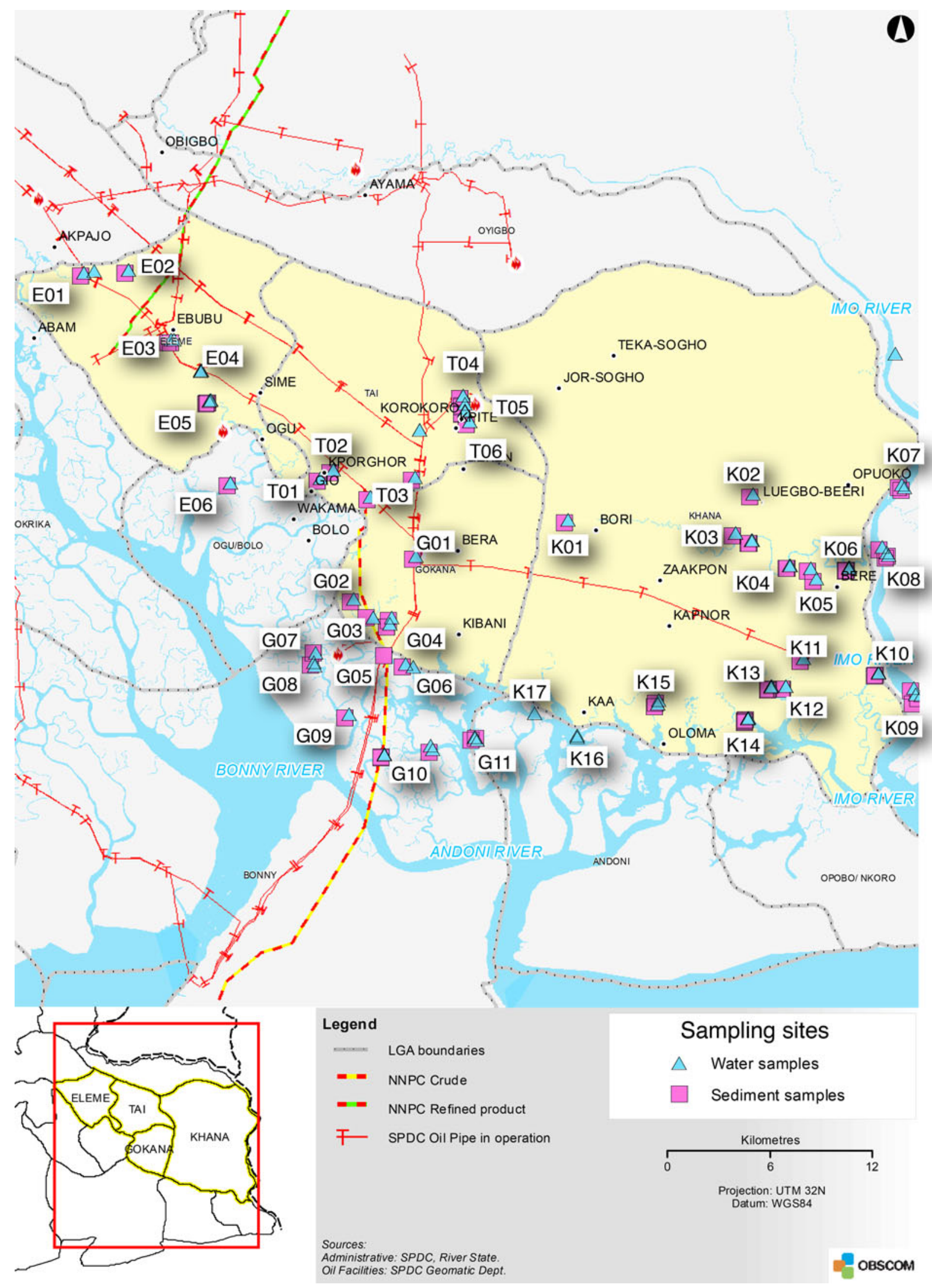


Department of Rivers State University of Science and Technology. Various locations around Ogoniland suitable for sampling were discussed in this expert group, before the plan was established and sampling commenced. It should be pointed out that the security situation in Ogoniland at the time of the investigation was better than for decades. Despite this, the fieldwork had to be carried out under stringent security conditions and at times sampling could not be carried out at all or was restricted in time and space.

Water quality parameters such as $\mathrm{pH}$, temperature, dissolved oxygen, and conductivity were measured with a HQ40D multi-meter (Hach Lange Ltd, Switzerland). A total of 41 sites in the four LGA's were visited for sampling of surface water (Fig. 1). The sites were selected based on accessibility, representativeness, security, and logistics. Exact locations, coordinates, and sampling times for each site can be found in the main UNEP report (2011). The first sampling round took place between 20 June and July 2, 2010, the second sampling between 19 and 30 July, 2010, the third between 17 Aug and 10 Sept 2010, with supplementary sampling 20-24 September and 11-19 November. The sites were sampled up to three times. Locations in Gokhana were sampled only in November due to the security situation. The sampling was done during midday and predominantly as the tide was going out. Due to security and logistical challenges, it proved to be impossible to sample at the same time each tide cycle. Sediment samples were taken at 37 sites, in conjunction with surface water sampling (Fig. 1).

Surface water samples were taken in water bodies such as rivers, streams, and ponds. Samples were collected as close as possible to the middle of the water body that could be reached from the shallow water using wader gear and a $2 \mathrm{~m}$ extendable metal arm. Samples were collected against the flow of the water, if any flow was discernible. Clean bottles supplied by the analytical laboratory were submerged $20-30 \mathrm{~cm}$ under the surface and rinsed once with the water at that position before the water sample was taken. When a boat was used, samples were collected at $20-40 \mathrm{~cm}$ depth using a Limnos water sampler (volume 2 L) (Limnos Ltd, Finland). Care was taken to minimize headspace in the sample bottles. Any equipment that was used to collect samples was washed using fresh water and a detergent and/or alcohol between each of the sampling sites to avoid cross-contamination. The equipment was thoroughly cleaned after each day. All samples were stored in cooling boxes with freezing elements during transport from the field. Sediment samples were stored in separate boxes from the water samples. Sampling information was collected on a standardized sampling protocol and entered into a sampling database.

Areas of calm water where sedimentation occurs may accumulate pollutants, which can later be re-suspended as a result of tidal mixing or flooding after heavy rains or as a result of biological processes (NRC 2003; ITOPF 2011a, b). Suitable sites for the collection of accumulated pollutants in the bottom material consisted of fine sediments including organic material. Sediment samples were collected at 37 locations (Fig. 1). At each location, five subsamples were collected in a plastic jar and thoroughly mixed with a spoon before the sample was taken and transferred to a glass jar for storage and transport to the laboratory. In most cases, a piston sampler with a diameter of $6 \mathrm{~cm}$ was used for sampling of sediment. Where the piston sampler could not be used, a Plexiglas coring tube (same diameter as the piston sampler) with rubber stoppers were used. Only the top $10 \mathrm{~cm}$ of the sediment core was used. During sampling care was taken to avoid flushing away the surface flock on top of the sediment.

To determine the concentrations of pollutants in the tissue of fish and shellfish (oysters, Anadara-bivalves and in one case periwinkles), samples were collected for analysis of petroleum hydrocarbons including polycyclic aromatic hydrocarbons (PAHs). Bivalves were collected and dissected according to standard procedures to avoid contamination. Fish and shellfish were collected from 28 sites, usually where sampling of water and sediment was carried out. Detailed locations can be found in Electronic Supplementary Material. In most cases, fish were purchased directly from the local fishermen in the process of fishing or transporting recently caught fish to make certain the fish had been caught locally. However, in cases where no fishermen engaged in fishing could be found at the time of the visits, fish were purchased from the local markets ( 8 occasions) close to the landing sites. From the moment the fish were purchased standard procedures for avoiding contamination was followed including rinsing with clean fresh water, storing in sealed plastic bags in cool boxes, dissecting and deep freezing. For each fish sample to be analyzed, tissue samples from four to six different individuals of the same species of fish (Table 4) of similar size were pooled to form a composite sample of about $50 \mathrm{~g}$ wet weight. Fish tissues were obtained by cutting the dorsal muscle from the fish with a scalpel and transfer it to a glass jar after having removed the skin. Shellfish were removed from their shell before being shipped.

While awaiting transport to the analytical laboratories (see below), water samples were stored at $0-2{ }^{\circ} \mathrm{C}$, and sediment and biota samples at -20 to $25^{\circ} \mathrm{C}$. Immediately before transport to the laboratories samples were packed with freeze elements in iceboxes and express shipped to Europe for analysis. Standard Chain-of-Custody protocols were maintained to ensure the integrity of the samples. Water and sediment samples were analyzed at ALcontrol in Chester, United Kingdom. Samples of animal tissue for analysis of extractable petroleum hydrocarbons (EPHs) 
including PAHs were shipped to ALS Scandinavia in Stockholm, Sweden. The packages for Chester and Stockholm arrived 2-4 days later to the laboratory where the samples were immediately processed. Over $90 \%$ of the samples arrived at the laboratory within $48 \mathrm{~h}$ of sampling. The samples that did not make it in $48 \mathrm{~h}$ arrived within $60 \mathrm{~h}$ and were still in good condition, i.e., the temperature of the samples was still below $0{ }^{\circ} \mathrm{C}$.

\section{Analyses \\ Extractable Petroleum Hydrocarbons}

Petroleum hydrocarbons are measured as aliphatics and aromatics with hydrocarbon chain lengths of C12-C16, C16-C21, C21-C35, and C35-C44. Particularly, the aromatic fraction is of interest from a toxicological perspective. In this report, to facilitate the interpretation of the data, the results for each sample have been summarized into EPHs. The analyses of sediments and tissue were to some degree affected by disturbances in the matrix. This affected to some extent the baseline for quantification. The results of the analyses show concentrations at or above the "quantification limit" which usually is about three times higher than the actual detection limit.

Petroleum hydrocarbons (aliphatic and aromatic species) were analyzed for speciated solvent ( $n$-hexane/acetone) EPHs, in the carbon number range C12-C44 by gas chromatography (GC) with flame ionization detection (FID). The extract was speciated into aliphatic and aromatic fractions. Ten grams of a dried and crushed sample was weighed and copper was added to prevent any interference from sulfur in the chromatography. A volume of solvent ( $n$-hexane/acetone) was added. This solvent also contained a surrogate, which was used to calculate recovery. The sample and solvent were shaken for a fixed time. Following partition of the hexane and acetone, an aliquot of the hexane layer was analyzed with GC with an internal standard (IS) added. For the aliphatic and aromatic fractionations, the extract was passed through a silica-based column. Quality assurance and quality control (QA/QC) samples were used. Standards covered the range required by the method.

\section{Polycyclic Aromatic Hydrocarbons}

PAHs consist of two or more fused benzene (aromatic) rings. PAHs are considered trace contaminants of freshwater and marine sediments all over the world (IPIECA 1991; Jinshu et al. 2004; ITOPF 2011a). They are recognized as major contributors to environmental pollution affecting aquatic ecosystems under the influence of human activities. PAHs are released to the environment from a number of anthropogenic activities, for example oil spills (Middleditch 1984; IPIECA 1991; Jenssen 1996; Heubeck et al. 2003; Kvenvolden and Cooper 2003; ITOPF 2011b). However, the combustion of fossil fuels from traffic, power generation, industrial processes such as smelters, refining, and a number of other anthropogenic activities also contribute to the build-up of PAHs in the environment. PAHs are also emitted from pyrogenic sources. Hence, incineration of garbage under non-optimal conditions (low temperatures), grass, and forest fires are other major sources of PAHs (NRC 2003; Lemieux et al. 2004; ITOPF 2011b). The pathways in which PAHs enter the environment are through the air, via water runoff, and through industrial and urban effluents. Some of the more common PAHs are known for their carcinogenic and mutagenic properties in mammals including humans (Jenssen 1996; Mumtaz et al. 1996; Nielsen et al. 1996; Bowyer et al. 2003; Heubeck et al. 2003; Peterson et al. 2003; Gehle 2009; Lerda 2010). The toxicity of PAHs depends on the relative composition of the individual PAHs in the sample. Some PAHs are considered less toxic or even harmless, while others are well known for their toxicity and mutagenicity (Kvenvolden and Cooper 2003; Gehle 2009). The standard method for reporting PAHs is the individual concentration of 16 common and relatively well-known PAHs and the total concentration of these often called the 16 USEPA PAHs (NOAA 1994, 2002; NRC 2003; Bojes and Pope 2007; Chan and Baba 2009; ITOPF 2012).

PAHs were analyzed using the CEM MARS microwave extraction unit and an Agilent Gas Chromatograph Mass Selective Detector (GC-MSD). The method analyses the 16 PAHs mentioned above and has been validated against sand, loam, and clay matrices and is accredited to ISO 17025 and the MCERTS standard (Environment Agency, UK, 2002). Soluble organic contaminants are extracted from sediment samples and surrogate solutions are added to monitor the extraction procedure. Compound identification was performed by selective ion monitoring (SIM) and quantification using IS calibration technique. QA/QC samples were used during the GC analysis. The standards used for quantitation contain the 16 USEPA PAHs and a five-point calibration is run.

\section{RESULTS}

\section{Physiocochemical Parameters}

The water temperature varied between 25.2 and $29.9{ }^{\circ} \mathrm{C}$ with an average of $26.9^{\circ} \mathrm{C}$ over the different sampling locations and dates, depending on the weather. Dissolved oxygen varied between 1.5 and $6.9 \mathrm{mg} \mathrm{L}^{-1}$ for the different sites and averaged $4.2 \mathrm{mg} \mathrm{L}^{-1}$, depending of the flow of 
Table 1 Extractable petroleum hydrocarbons (EPHs) and polyaromatic hydrocarbons (PAHs) in surface water. For location of the sampling sites, see Fig. 1 and Electronic Supplementary Material

\begin{tabular}{|c|c|c|c|c|c|c|c|c|}
\hline \multirow[t]{2}{*}{ Station } & \multicolumn{4}{|l|}{ EPH } & \multicolumn{4}{|l|}{ PAH } \\
\hline & Average $\left(\mu \mathrm{g} \mathrm{L}^{-1}\right)$ & Std error & Max & Min & Average $\left(\mu \mathrm{g} \mathrm{L}^{-1}\right)$ & Std error & Max & Min \\
\hline E01 & 111.7 & 136.7 & 267.0 & 10.0 & 0.7 & 1.1 & 2.0 & 0.1 \\
\hline E02 & 50.7 & 70.4 & 132.0 & 10.0 & 0.2 & 0.1 & 0.3 & 0.1 \\
\hline E03 & 100.0 & 106.8 & 218.0 & 10.0 & 0.2 & 0.2 & 0.4 & 0.1 \\
\hline E04 & 35.7 & 33.8 & 74.0 & 10.0 & 0.1 & 0.0 & 0.1 & 0.1 \\
\hline E05 & 68.7 & 101.6 & 186.0 & 10.0 & 0.2 & 0.1 & 0.3 & 0.1 \\
\hline E06 & 10.0 & 0.0 & 10.0 & 10.0 & 0.2 & 0.1 & 0.3 & 0.1 \\
\hline G01 & 10.0 & - & - & - & 0.1 & - & - & - \\
\hline G02 & 10.0 & - & - & - & 0.1 & - & - & - \\
\hline G03 & 11.5 & 2.1 & 13.0 & 10.0 & 0.1 & 0.0 & - & - \\
\hline G04 & 2350.0 & - & - & - & 0.0 & - & - & - \\
\hline G05 & - & - & - & - & - & - & - & - \\
\hline G06 & 682.0 & 944.7 & 1350.0 & 14.0 & 0.1 & 0.0 & 0.1 & 0.1 \\
\hline G07 & 11.0 & - & - & - & 0.1 & - & - & - \\
\hline G08 & 13.0 & - & - & - & 0.1 & - & - & - \\
\hline G09 & 10.0 & - & - & - & 0.1 & - & - & - \\
\hline G10 & 968.7 & 1655.3 & 2880.0 & 10.0 & 0.1 & 0.0 & 0.1 & 0.1 \\
\hline G11 & 2480.0 & 4278.2 & 7420.0 & 10.0 & 0.5 & 0.6 & 1.2 & 0.1 \\
\hline K01 & 10.0 & - & - & - & 0.1 & - & - & - \\
\hline K02 & 72.5 & 88.4 & 135.0 & 10.0 & 0.1 & 0.0 & 0.1 & 0.1 \\
\hline K03 & 10.0 & 0.0 & 10.0 & 10.0 & 0.1 & 0.0 & 0.1 & 0.1 \\
\hline K04 & 10.0 & 0.0 & 10.0 & 10.0 & 0.1 & 0.0 & 0.1 & 0.1 \\
\hline K05 & 10.0 & 0.0 & 10.0 & 10.0 & 0.1 & 0.0 & 0.1 & 0.1 \\
\hline K06 & 10.0 & 0.0 & 10.0 & 10.0 & 0.1 & 0.0 & 0.1 & 0.1 \\
\hline K07 & 10.0 & 0.0 & 10.0 & 10.0 & 0.1 & 0.0 & 0.1 & 0.1 \\
\hline K08 & 19.0 & 12.7 & 28.0 & 10.0 & 0.1 & 0.0 & 0.1 & 0.1 \\
\hline K09 & 28.0 & 25.5 & 46.0 & 10.0 & 0.1 & 0.0 & 0.1 & 0.1 \\
\hline K10 & 10.0 & 0.0 & 10.0 & 10.0 & 0.1 & 0.0 & 0.1 & 0.1 \\
\hline K11 & 363.3 & 612.0 & 1070.0 & 10.0 & 0.1 & 0.0 & 0.1 & 0.1 \\
\hline K12 & 10.0 & 0.0 & 10.0 & 10.0 & 0.1 & 0.0 & 0.1 & 0.1 \\
\hline K13 & 10.0 & 0.0 & 10.0 & 10.0 & 0.1 & 0.0 & 0.1 & 0.1 \\
\hline K14 & 10.0 & 0.0 & 10.0 & 10.0 & 0.1 & 0.0 & 0.1 & 0.1 \\
\hline K15 & 86.3 & 132.2 & 239.0 & 10.0 & 0.1 & 0.0 & 0.1 & 0.1 \\
\hline K16 & 10.0 & 0.0 & 10.0 & 10.0 & 0.1 & 0.0 & 0.1 & 0.1 \\
\hline K17 & 372.3 & 515.9 & 963.0 & 10.0 & 0.1 & 0.0 & 0.1 & 0.1 \\
\hline T01 & 47.0 & 64.1 & 121.0 & 10.0 & 0.1 & 0.0 & 0.1 & 0.1 \\
\hline T02 & 10.7 & 1.2 & 12.0 & 10.0 & 0.1 & 0.0 & 0.1 & 0.1 \\
\hline T03 & 50.3 & 69.9 & 131.0 & 10.0 & 0.1 & 0.0 & 0.1 & 0.1 \\
\hline T04 & 10.0 & 0.0 & 10.0 & 10.0 & 0.1 & 0.0 & 0.1 & 0.1 \\
\hline T05 & 56.0 & 79.7 & 148.0 & 10.0 & 0.1 & 0.0 & 0.1 & 0.1 \\
\hline T06 & 44.0 & 58.9 & 112.0 & 10.0 & 0.1 & 0.0 & 0.1 & 0.1 \\
\hline
\end{tabular}

the water and aquatic flora. Salinity and conductivity went from almost totally fresh water $\left(3.0 \mu \mathrm{S} \mathrm{cm}^{-1}\right)$ up to $17.7 \mathrm{ppt}\left(27600 \mu \mathrm{S} \mathrm{cm}^{-1}\right)$ in the mangrove areas directly influenced by the tide. The $\mathrm{pH}$ value varied similarly between 4.7 and 7.3 and averaging 6.1 with the lower values in the more stagnant water bodies inland. 
Table 2 Concentrations of extractable petroleum hydrocarbons (EPHs) in drinking water from Ogoniland. Benzene concentrations were analyzed from a majority of the wells

\begin{tabular}{|c|c|c|c|c|c|c|}
\hline LGA & Sample ID number & Easting & Northing & Well type & $\mathrm{EPH}\left(\mu \mathrm{g} \mathrm{L}^{-1}\right)$ & Benzene $\left(\mu \mathrm{g} \mathrm{L}^{-1}\right)$ \\
\hline Eleme & 001-005-MED-101 & 292337.00 & 529419.00 & Bore-well & 19900.00 & 8370.00 \\
\hline Eleme & 001-005-BH-02 & 293036.00 & 529204.00 & Bore-well & 4280.00 & 0.65 \\
\hline Eleme & 001-005-BH-04 & 292622.00 & 529954.00 & Bore-well & 317.00 & 0.65 \\
\hline Eleme & 001-005-BH-103 & 292494.00 & 529220.00 & Bore-well & 1320.00 & 161.00 \\
\hline Eleme & 001-005-BH-104 & 292537.00 & 529161.00 & Bore-well & 233.00 & 0.65 \\
\hline Eleme & 001-005-BW-100 & 292824.00 & 529568.00 & Bore-well & 42200.00 & 7090.00 \\
\hline Eleme & 001-005-BH-102 & 292343.00 & 529425.00 & Bore-well & 20200.00 & 9280.00 \\
\hline Eleme & 004-006-BH-105 & 292355.00 & 529650.00 & Bore-well & 299.00 & 0.65 \\
\hline Eleme & 001-002-BH-102 & 294053.00 & 528548.00 & Bore-well & 642.00 & 0.65 \\
\hline Eleme & 001-005-GW-104 & 292479.00 & 529671.00 & Hand-dug well & 20300.00 & 7140.00 \\
\hline Eleme & 001-009-HW-01 & 295675.00 & 527820.00 & Hand-dug well & 12.00 & 0.65 \\
\hline Eleme & 001-005-HW-100 & 292914.00 & 529315.00 & Hand-dug well & 39.30 & 0.65 \\
\hline Gokana & 019-014-GW-100 & 308385.00 & 514030.00 & Hand-dug well & 63.00 & 0.65 \\
\hline Gokana & 019-014-GW-102 & 308411.00 & 514064.00 & Hand-dug well & 11500.00 & 0.65 \\
\hline Gokana & 019-035-HW-104 & 309480.00 & 514389.00 & Hand-dug well & 12.00 & 0.65 \\
\hline Gokana & 019-035-HW-12 & 309477.00 & 514392.00 & Hand-dug well & 21.00 & - \\
\hline Gokana & 019-020-HW-15 & 308887.00 & 513109.00 & Hand-dug well & 4240.00 & - \\
\hline Gokana & 019-007-HW-101 & 308737.00 & 515315.00 & Hand-dug well & 15.00 & 0.65 \\
\hline Tai & 008-002-HW-01 & 312865.89 & 524299.65 & Hand-dug well & 14.00 & - \\
\hline Tai & 008-002-HW-03 & 312798.00 & 523604.00 & Hand-dug well & 12.00 & - \\
\hline Tai & 008-002-HW-04 & 312747.00 & 523599.00 & Hand-dug well & 12.00 & - \\
\hline Tai & 008-002-HW-11 & 312871.00 & 523654.00 & Hand-dug well & 11.00 & - \\
\hline Tai & 008-002-HW-12 & 312771.00 & 523635.00 & Hand-dug well & 11.00 & - \\
\hline Tai & 008-002-HW-13 & 312779.00 & 523475.00 & Hand-dug well & 13.00 & - \\
\hline Tai & 005-009-HW-04 & 309360.00 & 524575.00 & Hand-dug well & 53.00 & 0.65 \\
\hline Tai & 009-003-HW-101 & 306246.00 & 522066.00 & Hand-dug well & 54.70 & 0.65 \\
\hline Tai & 009-003-HW-102 & 306277.00 & 522038.00 & Hand-dug well & 154.00 & 0.65 \\
\hline Tai & 008-002-HW-100 & 312760.00 & 524379.00 & Hand-dug well & 59.40 & 0.65 \\
\hline
\end{tabular}

\section{EPHs in Water}

The results of the water analysis show clearly elevated concentrations at most of the sampling sites. Surface water levels from the streams and rivers averaged $773 \mu \mathrm{g} \mathrm{L}^{-1}$, but ranged from below the quantification limit to $7420 \mu \mathrm{g} \mathrm{L}^{-1}$. There is a clear correlation between sites with high concentrations of EPHs in the water with high concentrations in the sediments from the same locations (see below). PAH levels in water samples were generally below the quantification limit with a maximum of $2.0 \mu \mathrm{g} \mathrm{L}^{-1}$ (Table 1).

Water samples taken in the local drinking wells used by communities in Ogoniland varied dramatically in the concentrations of EPHs. Many samples particularly from hand-dug wells in Tai showed levels ranging from 11 to $154 \mu \mathrm{g} \mathrm{L}^{-1}$. Bore wells sometimes showed high levels of EPHs: the highest concentrations recorded were 20 000-42 $200 \mu \mathrm{g} \mathrm{L}^{-1}$ (Table 2). Furthermore, in bore wells in Eleme very high levels of benzene were also noted: up to $9280 \mu \mathrm{g} \mathrm{L}^{-1}$. The World Health Organization (WHO) guideline value for benzene in drinking water is $10 \mu \mathrm{g} \mathrm{L}^{-1}$ (WHO 2003).

The presence of oil in creeks and water bodies were obvious as a sheen on the surface or as oil slicks of considerable size (Fig. 2). From the ground it was difficult to assess the size of these slicks but overflights showed oil more or less covering every surface of water for several square kilometers.

\section{EPHs in Sediments}

The results of the analyses are shown in Table 3 . The results clearly show elevated concentrations of EPHs in all four LGAs. The highest concentrations were found in stations in Gokhana, where EPH concentrations ranged from 279 to $17900 \mathrm{mg} \mathrm{kg}^{-1}$ (Fig. 3). In Eleme, one station showed $9680 \mathrm{mg} \mathrm{kg}^{-1}$ (Fig. 4) and in Khana two stations 


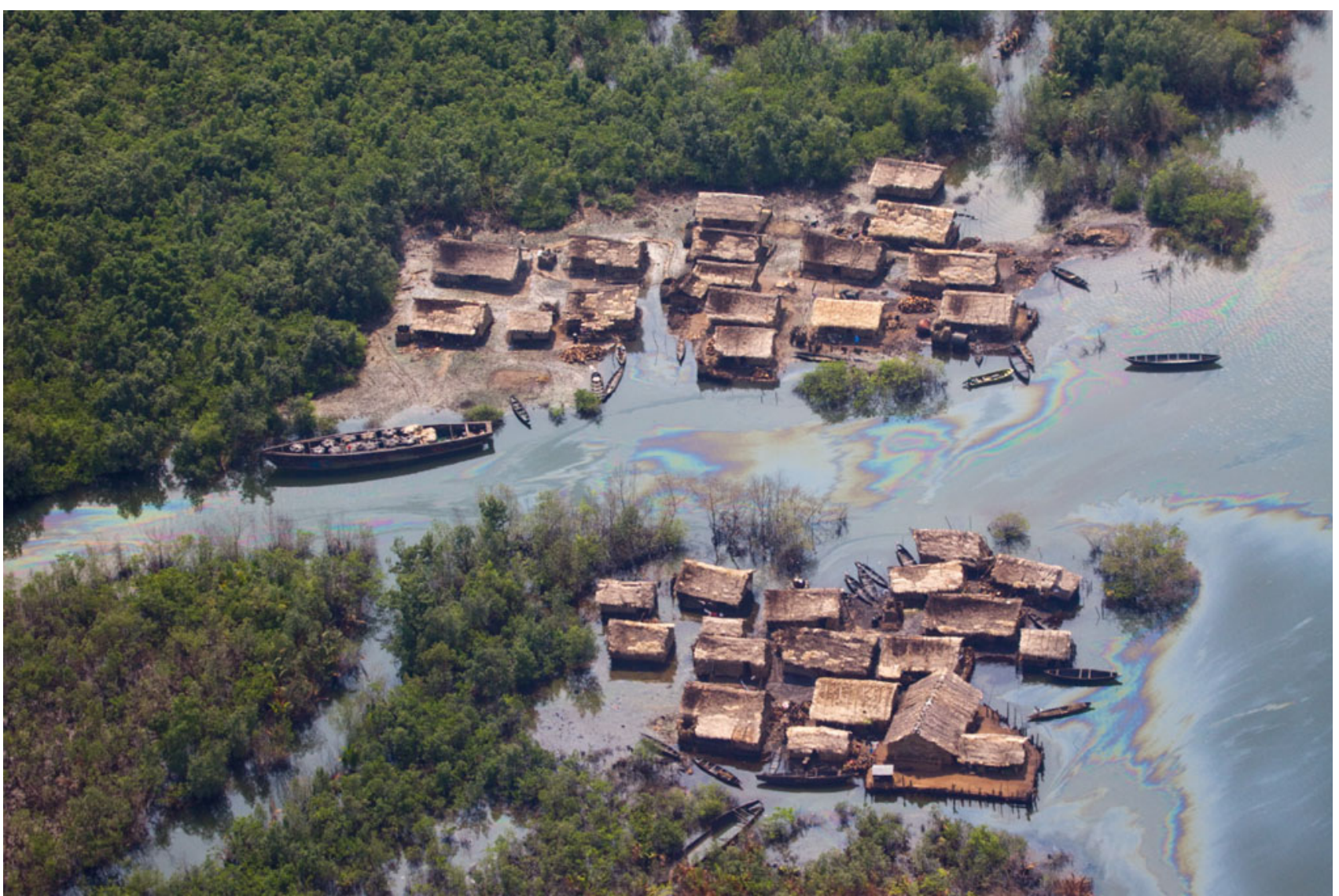

Fig. 2 Particularly in Gokhana LGA, an oil sheen was seen on the water surface at most sampling locations. The photo also shows vessels used for transport of oil (Photo: UNEP 2011)

showed 2150-4520 $\mathrm{mg} \mathrm{kg}^{-1}$ (Fig. 5). In Tai, levels reached $12000 \mathrm{mg} \mathrm{kg}^{-1}$ at the station with the highest concentration (Fig. 6).

The concentrations of PAHs in sediments are slightly above the quantification limits in most of the samples from the four LGAs. The exceptions are two sites in Gokhana (Fig. 3) and one in Tai (Fig. 6), where high concentrations were found. The PAH concentrations in Gokhana were up to $8 \mathrm{mg} \mathrm{kg}^{-1}$, while $7 \mathrm{mg} \mathrm{kg}^{-1}$ was found in the most contaminated sites in Tai.

\section{Petroleum Hydrocarbons in Biota}

The concentrations of EPHs in the tissues of fish and shellfish show an uneven picture of contamination of some of the samples, mainly in the form of the fractions C16$\mathrm{C} 35$ of the total aliphatics and aromatics. Out of the total of 88 samples of fish and shellfish analyzed, less than $10 \%$ showed measurable concentrations of EPH. The concentrations were up to $67.7 \mathrm{mg} \mathrm{kg}^{-1}$ in molluscs and $65.0 \mathrm{mg} \mathrm{kg}^{-1}$ wet weight in fish (Table 4). PAH concentrations ranged up to $62.0 \mu \mathrm{g} \mathrm{kg}^{-1}$ in molluscs and $15.0 \mu \mathrm{g} \mathrm{kg}^{-1}$ in fish (Table 4).

\section{DISCUSSION}

The measurements of physic-chemical parameters showed expected results considering the rather different conditions in the inner northern parts of the area compared to the southern more maritime areas. The water temperature variation is dependant on the season of the year and the weather. The concentrations of dissolved oxygen are dependent of the flow of the water and the presence of aquatic flora. Salinity and conductivity were predictably low in northern parts of the area and much higher in the southern mangrove areas directly influenced by the tides. The $\mathrm{pH}$ values were within normal ranges, with the lower values in the more stagnant water bodies inland.

Overflights with helicopters over Ogoniland during the present investigations showed extensive surface water contamination, spills often covered many square kilometers, particularly in the Gokhana LGA (Fig. 8). In most cases, where oil was observed floating on the water, it was impossible to determine the source of the contamination, as tidal movement carried the contamination in different directions. However, oil spills in the region originate from leaks in pipelines, wellheads, and flow stations, and from 
Table 3 Extractable petroleum hydrocarbons (EPHs) and polycyclic aromatic hydrocarbons (PAHs) in sediments. For location of the sampling sites, see Fig. 1 and Electronic Supplementary Material

\begin{tabular}{|c|c|c|c|c|c|c|c|c|}
\hline \multirow[t]{2}{*}{ Station } & \multicolumn{4}{|l|}{ EPH } & \multicolumn{4}{|l|}{ PAH } \\
\hline & Average $\left(\mathrm{mg} \mathrm{kg}^{-1}\right)$ & Std error & Max & Min & Average $\left(\mu \mathrm{g} \mathrm{kg}^{-1}\right)$ & Std error & Max & Min \\
\hline E01 & 542.3 & 262.1 & 904.0 & 32.8 & 971.0 & 560.7 & 2030.0 & 118.0 \\
\hline E02 & 374.4 & 317.8 & 1010.0 & 55.9 & 1442.0 & 1324.0 & 4090.0 & 118.0 \\
\hline E03 & 9680.0 & 1766.8 & 12100.0 & 6240.0 & 1710.0 & 398.9 & 2420.0 & 1040.0 \\
\hline E04 & 176.3 & 76.2 & 326.0 & 76.8 & 118.0 & 0.0 & 118.0 & 118.0 \\
\hline E05 & 54.6 & 11.1 & 65.7 & 43.5 & 118.0 & 0.0 & 118.0 & 118.0 \\
\hline G01 & 16500.0 & - & - & - & 7950.0 & - & - & - \\
\hline G02 & 1530.0 & - & - & - & 286.0 & - & - & - \\
\hline G03 & 12100.0 & - & - & - & 1260.0 & - & - & - \\
\hline G04 & 17900.0 & - & - & - & 4760.0 & - & - & - \\
\hline G05 & 12100.0 & - & - & - & 835.0 & - & - & - \\
\hline G06 & 864.0 & - & - & - & 155.0 & - & - & - \\
\hline G07 & 11100.0 & - & - & - & 1700.0 & - & - & - \\
\hline G08 & 361.0 & - & - & - & 118.0 & - & - & - \\
\hline G09 & 6570.0 & - & - & - & 759.0 & - & - & - \\
\hline G10 & 6230.0 & 1459.9 & 8630.0 & 3590.0 & 2025.0 & 159.2 & 2220.0 & 1830.0 \\
\hline G11 & 278.5 & 131.5 & 410.0 & 147.0 & 118.0 & - & - & - \\
\hline K01 & 37.1 & 35.6 & 72.7 & 1.6 & 118.0 & 0.0 & 118.0 & 118.0 \\
\hline K02 & 82.0 & 65.0 & 147.0 & 17.0 & 118.0 & 0.0 & 118.0 & 118.0 \\
\hline K03 & 72.8 & 19.9 & 92.6 & 52.9 & 118.0 & 0.0 & 118.0 & 118.0 \\
\hline K04 & 356.0 & 231.0 & 587.0 & 125.0 & 118.0 & 0.0 & 118.0 & 118.0 \\
\hline K05 & 678.9 & 645.7 & 1970.0 & 10.6 & 118.0 & 0.0 & 118.0 & 118.0 \\
\hline K06 & 353.0 & - & - & - & 470.0 & - & - & - \\
\hline K07 & 2150.0 & - & - & - & 118.0 & - & - & - \\
\hline K08 & 171.0 & - & - & - & 118.0 & - & - & - \\
\hline K09 & 205.5 & 56.5 & 262.0 & 149.0 & 133.0 & 14.5 & 147.0 & 118.0 \\
\hline K10 & 77.2 & 12.1 & 95.0 & 54.0 & 118.0 & 0.0 & 118.0 & 118.0 \\
\hline K11 & 146.6 & 89.7 & 325.0 & 41.8 & 118.0 & 0.0 & 118.0 & 118.0 \\
\hline K12 & 78.6 & 74.7 & 228.0 & 3.7 & 118.0 & 0.0 & 118.0 & 118.0 \\
\hline K13 & 112.6 & 84.5 & 365.0 & 8.0 & 165.0 & 46.5 & 304.0 & 118.0 \\
\hline K14 & 19.9 & 12.7 & 44.5 & 2.5 & 118.0 & 0.0 & 118.0 & 118.0 \\
\hline K15 & 4520.0 & - & - & - & 1570.0 & - & - & - \\
\hline T01 & 181.0 & 42.3 & 265.0 & 130.0 & 118.0 & 0.0 & 118.0 & 118.0 \\
\hline T02 & 110.2 & 12.0 & 134.0 & 95.6 & 118.0 & 0.0 & 118.0 & 118.0 \\
\hline T03 & 12000.0 & - & - & - & 6950.0 & - & - & - \\
\hline T04 & 13.6 & 8.0 & 27.8 & 0.1 & 118.0 & 0.0 & 118.0 & 118.0 \\
\hline T05 & 68.1 & 33.5 & 127.0 & 11.0 & 118.0 & 0.0 & 118.0 & 118.0 \\
\hline T06 & 19.8 & 4.1 & 26.6 & 12.5 & 118.0 & 0.0 & 118.0 & 118.0 \\
\hline
\end{tabular}

spills from boats or other vehicles (Human Rights Watch 2005; Idemudia 2009; UNEP 2011; CIA 2012). The spills may be due to corrosion and lack of maintenance of the infrastructure but they are also the result of leaks from pipelines and wellheads that have been damaged during attempts to steal oil. A large part of the spilt oil originates from spills during transport of stolen oil under very primitive conditions and very polluting "refining" of such oil at the village level (Figs. 7, 8).

\section{Petroleum Hydrocarbons in Water}

The results of the water analysis show clearly elevated concentrations of EPHs in most places where samples were 


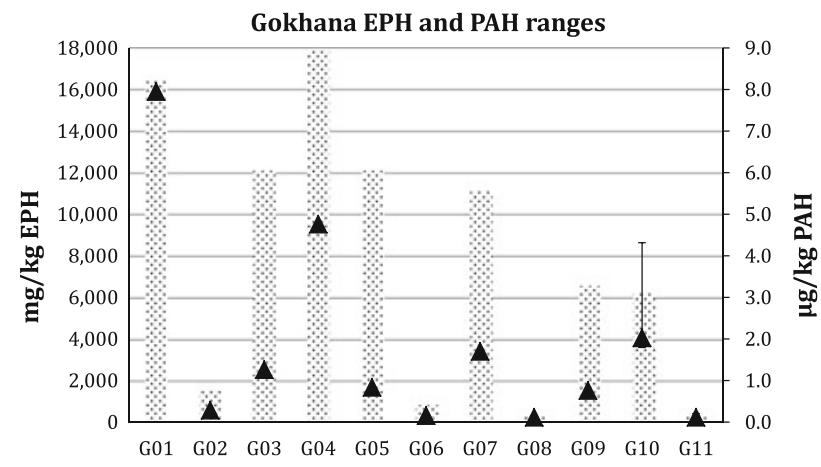

Fig. 3 Extractable petroleum hydrocarbons (bars) and polycyclic aromatic hydrocarbons (triangles) levels in Gokhana LGA in Ogoniland. Error bars Ranges. For sampling locations see Fig. 1 and Electronic Supplementary Material

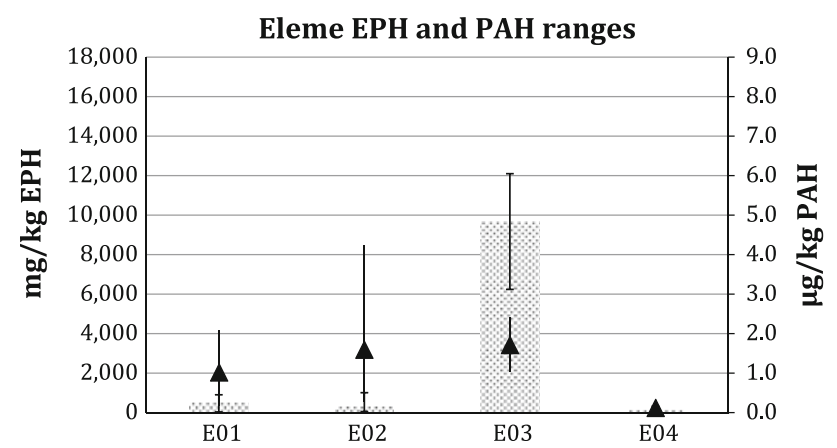

Fig. 4 Extractable petroleum hydrocarbons (bars) and polycyclic aromatic hydrocarbons (triangles) levels in Eleme LGA in Ogoniland. Error bars Ranges. For sampling locations see Fig. 1 and Electronic Supplementary Material

taken. Concentrations of several hundred $\mu \mathrm{g} \mathrm{L}{ }^{-1}$ EPHs in rivers and creeks cause impacts to sensitive organisms and in waters with several thousand $\mu \mathrm{g} \mathrm{L}^{-1}$, even very tolerant organisms are likely to disappear (NRC 2003). Moffat and Linden (1995) reported similar concentrations of dissolved petroleum hydrocarbons in surface waters as those reported here as common concentrations in the Niger Delta in the
Tai EPH and PAH ranges

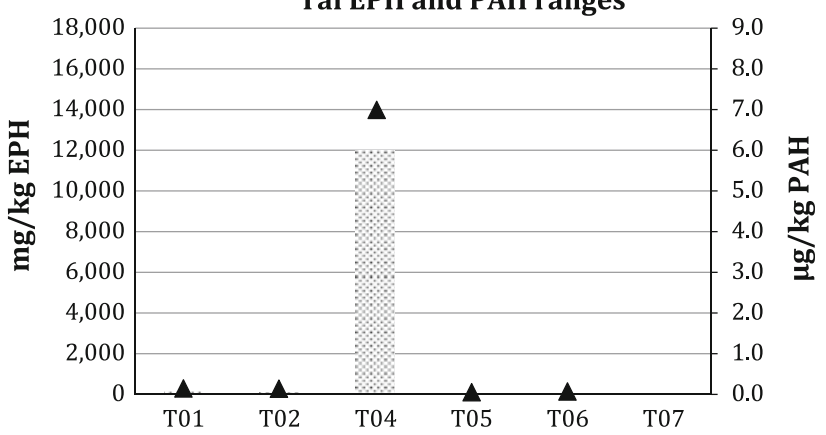

Fig. 6 Extractable petroleum hydrocarbons (bars) and polycyclic aromatic hydrocarbons (triangles) levels in Tai LGA in Ogoniland. Error bars Ranges. For sampling locations see Fig. 1 and Electronic Supplementary Material

1990s. However, much higher concentrations were reported locally, for example Ibiebele (1986) reported concentrations of $53000-62700 \mu \mathrm{g} \mathrm{L}^{-1}$ in refinery waste water from the Niger Delta.

EPH levels of several hundred $\mu \mathrm{g} \mathrm{L}^{-1}$ in water samples (as shown in Table 2) cause a number of environmental effects and render freshwater unfit for human consumption (NRC 2003; UNEP 2011). In this investigation, concentrations of several thousand $\mu \mathrm{g} \mathrm{L}^{-1}$ or more were found. The WHO does not give any maximum or guideline value for mineral oil in drinking water but the Nigerian drinking water standard is $3 \mu \mathrm{g} \mathrm{L}^{-1}$ (EGASPIN 2002). The concentrations found here are several thousand times above the Nigerian water standard and is clearly not suitable for consumption. The very high levels of the known carcinogen benzene in several wells in Eleme LGA (Table 2) illustrate the threats to human health from the contaminated water in the area. The WHO guideline value for benzene in drinking water is $10 \mu \mathrm{g} \mathrm{L}^{-1}$ and the results from the wells show levels that are more than 600 times higher-in one case nearly 1000 times the WHO guideline value (2003).
Fig. 5 Extractable petroleum hydrocarbons (bars) and polycyclic aromatic hydrocarbons (triangles) levels in Khana LGA in Ogoniland. Error bars Ranges. For sampling locations see Fig. 1 and Electronic Supplementary Material

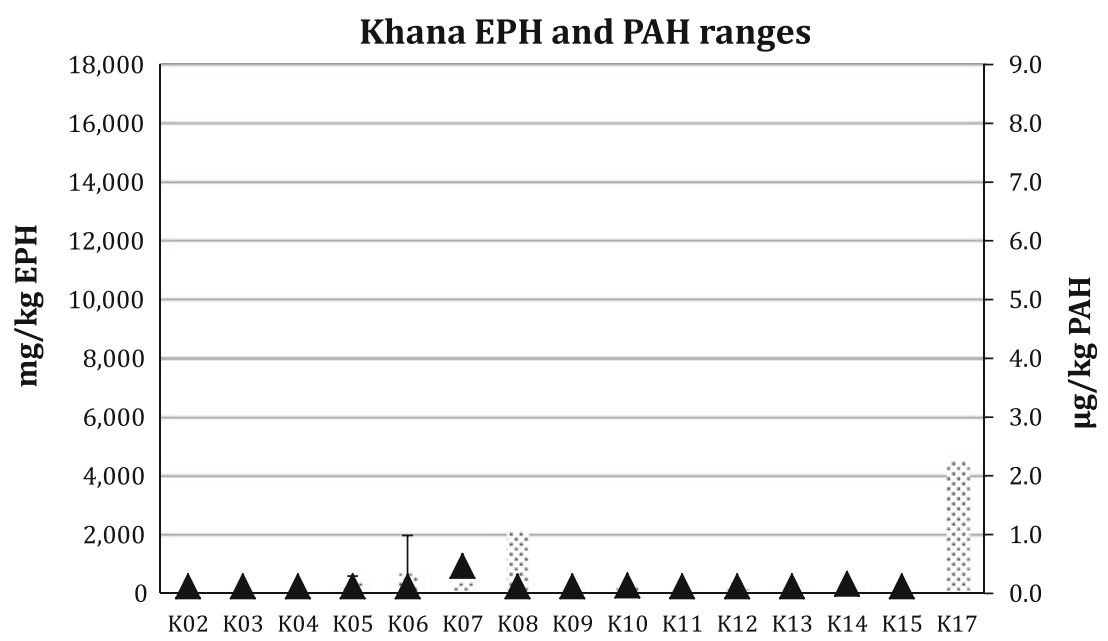

(C) Royal Swedish Academy of Sciences 2013 www.kva.se/en 
Table 4 Concentrations of extractable petroleum hydrocarbons (EPHs) and polycyclic aromatic hydrocarbons (PAHs) in biota

\begin{tabular}{|c|c|c|c|c|c|c|c|c|c|c|}
\hline Scientific name & Nigerian name & $N$ & $\begin{array}{l}\mathrm{EPH} \\
\left(\mathrm{mg} \mathrm{kg}^{-1}\right)\end{array}$ & $\begin{array}{l}\text { Max } \\
\text { value }\end{array}$ & $\begin{array}{l}\text { Min } \\
\text { value }\end{array}$ & $\begin{array}{l}\text { Std } \\
\text { dev }\end{array}$ & $\begin{array}{l}\text { PAH } \\
\left(\mu \mathrm{g} \mathrm{kg}^{-1}\right)\end{array}$ & $\begin{array}{l}\text { Max } \\
\text { value }\end{array}$ & $\begin{array}{l}\text { Min } \\
\text { value }\end{array}$ & $\begin{array}{l}\text { Std } \\
\text { dev }\end{array}$ \\
\hline Anadara senilis & Blood cockle & 12 & 32.8 & 67.7 & 0.0 & 33.7 & 11.9 & 62.0 & 0.0 & 21.9 \\
\hline $\begin{array}{l}\text { Chrysichthys } \\
\text { nigrodigitatus }\end{array}$ & Catfish & 1 & 3.0 & 3.0 & 3.0 & - & 15.0 & 15.0 & 15.0 & - \\
\hline Crassostrea gasar & $\begin{array}{l}\text { Mangrove } \\
\text { oyster }\end{array}$ & 9 & 0.0 & 0.0 & 0.0 & 0.0 & 0.0 & 0.0 & 0.0 & 0.0 \\
\hline Mugil cephalus & Mullet & 2 & 3.3 & 3.3 & 3.3 & 0.0 & 8.7 & 10.0 & 7.3 & 1.9 \\
\hline Periophthalmus barbarus & Mudskipper & 7 & 18.6 & 65.0 & 0.0 & 31.7 & 3.7 & 13.0 & 0.0 & 6.3 \\
\hline Pseudotolithus sp. & Croaker & 1 & 3.0 & 3.0 & 3.0 & - & 14.0 & 14.0 & 14.0 & - \\
\hline Sphyraena sp. & Barracuda & 2 & 3.8 & 4.2 & 3.3 & 0.6 & 6.6 & 7.6 & 5.6 & 1.4 \\
\hline Tilapia guineensis & Tilapia & 2 & 15.4 & 28.1 & 2.7 & 17.9 & 9.6 & 6.1 & 13.0 & 4.9 \\
\hline Tympanotonus fuscatus & Periwinkle & 1 & 8.3 & 8.3 & 8.3 & - & 35.0 & - & - & - \\
\hline
\end{tabular}

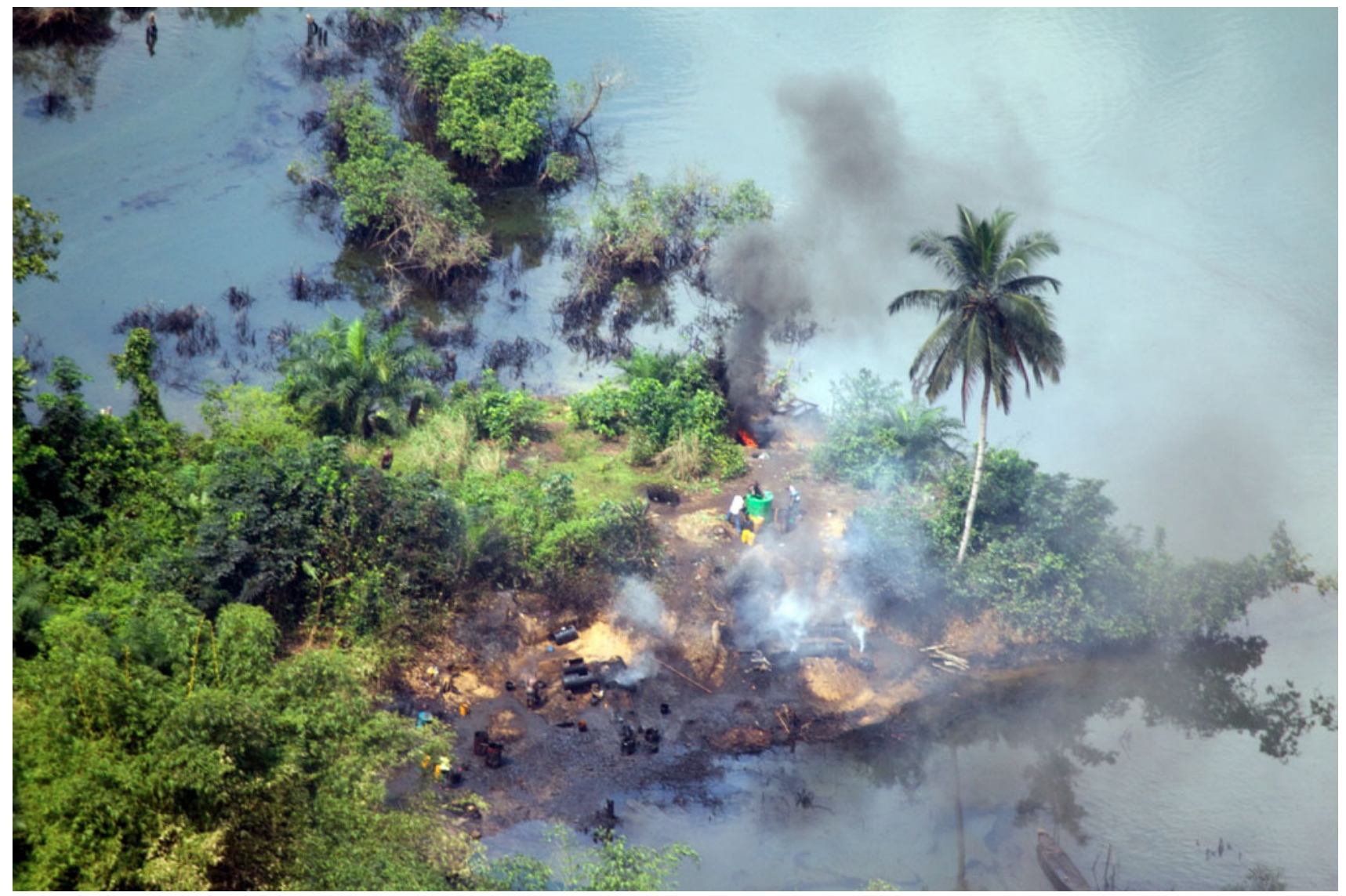

Fig. 7 Artisanal refining operation in Gokhana LGA. This kind of very polluting activity goes on in parts of the Niger Delta and is based on stolen crude oil (Photo by UNEP)

\section{Petroleum Hydrocarbons in Sediments}

The concentrations found in sediments over much of the area indicate clearly elevated levels. Concentrations of one hundred or several hundred $\mathrm{mg} \mathrm{kg}^{-1}$ were found in Khana, Tai, and Eleme. Concentrations of several thousand $\mathrm{mg} \mathrm{kg}^{-1}$ were found in most of the stations in Gokhana and some of the stations in the other LGAs. However, in several stations in Tai and Khana, the concentrations were lower than what might have been expected considering the extensive surface contamination. The reason for this may be that oil concentrations may be very significant at the surface but due to relatively calm conditions only a small fraction of the oil is emulsified and distributed to the 


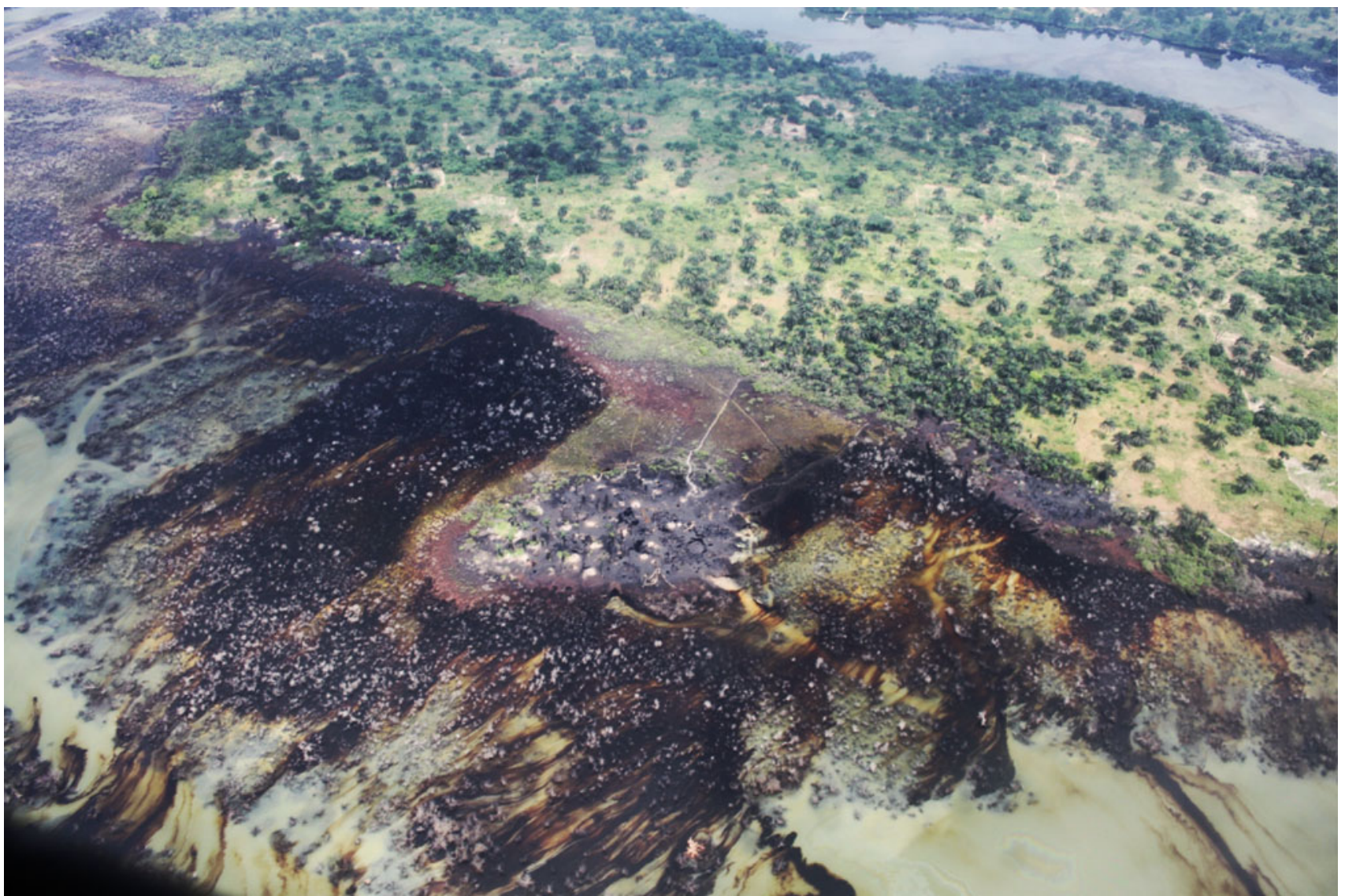

Fig. 8 Oil spills in the creeks southeast of Bodo, Gokhana. Photo by Thorsten Kallnischkies (Photo: UNEP)

sediments. A large number of studies of petroleum hydrocarbon concentrations in more or less chronically contaminated freshwater and seabed sediments have been carried out around the world. The results have been summarized for example by the National Research Council in the USA (NRC 2003). In conclusion, the studies show that sediment concentrations of EPH in areas far from urbanized coastal areas are often in the range of $20-50 \mathrm{mg} \mathrm{kg}^{-1}$. Concentrations in the range of fifty to several hundred $\mathrm{mg} \mathrm{kg}^{-1}$ are often found in coastal sediments where anthropogenic activities are intensive such as in densely trafficked ship channels, near marinas and similar areas. Near direct point sources of oil contamination, such as water-cooled oil refineries and oil terminals or areas that are exposed to large volumes of oil due to spills the concentrations may be thousand to several thousand $\mathrm{mg} \mathrm{kg}^{-1}$. A study in Iko River estuary (Nigeria) showed EPH of between 6.1 and $35.27 \mathrm{mg} \mathrm{kg}^{-1}$ in the sediment and in contaminated areas near an oil field in Akwa Ibom State (Nigeria) the sediment levels were up to $372.4 \mathrm{mg} \mathrm{kg}^{-1}$ (Essien et al. 2011). In colder environments, where the weathering and degradation processes are slower, concentrations may be significantly higher (Brakstad and Bonaunet 2006; Singsaas and Lewis 2011; UNEP 2011).
This investigation of the concentrations of EPHs in four LGAs in Ogoniland shows that sediments are contaminated over large areas, and at certain locations to very high levels.

In connection with acute oil spills very high concentrations of EPHs may be found in affected sediments. Such concentrations often drop rather rapidly to background levels if the conditions for degradation are favorable. However, if conditions are less favorable for natural degradation, weathering, and dispersion, the petroleum hydrocarbons may remain a pollution problem for many years. Factors of importance for the rate of degradation are temperature, sunlight, oxygen, nutrients, microbial communities, and physical energy such as stream flow, tidal flushing and waves. Also the type of oil will be important for the degradation processes. Certain heavy oils with high concentrations of asphaltenes may turn into solid asphalt aggregates and remain on beaches for many years. Hence, it is difficult to compare the concentrations found in $\mathrm{Og}$ oniland with concentrations found elsewhere following accidental release of oil. It may also be important to add that very large amounts of oil may float on the surface of the water but not really contaminate the sediment in a significant way. A case in point may be the Gulf War in 1990-1991, where the contamination of seabed sediments 
was quite high in certain enclosed areas where the force of waves and wind more or less forced the oil into deeper areas. However, over large areas of open seabed the concentrations were generally quite low despite the large quantities of oil that floated on the surface. Particularly, high concentrations were found in littoral supra-tidal sediments. Here, investigations one year after the oil contaminated the coast reported concentrations of up to $36000 \mathrm{mg} \mathrm{kg}^{-1}$ in sandflat sediment (Sauer et al. 1993). Following the Deepwater Horizon incident in the Gulf of Mexico in 2010 one study (Kostka et al. 2011) showed concentrations up to $4500 \mathrm{mg} \mathrm{kg}^{-1}$ could be found in beach sand. Following the Prestige oil spill in northern Spain in 2002, surveys showed total hydrocarbon concentrations in the sediment between 3.7 and $787 \mathrm{mg} \mathrm{kg}^{-1}$ during and after the spill (Juanes et al. 2007).

\section{Concentrations of PAH}

Compared with levels from other parts of the world, the PAH concentrations found in this investigation are typical for areas under influence from intensive anthropogenic activities. The elevated levels found in Gokhana and Eleme are comparable to those expected to be found in shallow water sediments in coastal areas with intensive industrial activities and very close to urban areas (Soclo et al. 2000; Jinshu et al. 2004). For example, in contaminated coastal sediments along the coast of Lebanon, levels up to $174 \mathrm{mg} \mathrm{kg}^{-1}$ were found in 2007 (Lindén and Rust 2008). The concentrations of PAHs in heavily contaminated industrial sites in Calabar (Nigeria) varied from 1.8 to $334 \mathrm{mg} \mathrm{kg}^{-1}$ (Nganje et al. 2006). About 10 years after the Gulf War, the concentrations of total PAHs in the shoreline sediments in Saudi Arabia were still high, up to and over $100 \mathrm{mg} \mathrm{kg}^{-1}$ (Bejarano and Michel 2010). The authors point out the importance of the landscape and geomorphology in the distribution and persistence oil in the sediments. Table 5 describes concentrations of PAHs in sediments from various ports of the world.

There are various views on how to determine whether certain levels of PAHs in marine or freshwater sediments should be considered "contaminated" or not. Hence, various assessments based on "effects range low" (ERL), "effects range medium" (ERM), "threshold effects limits," and "probable effects limits" (TEL/PEL) have been made for total polyaromatic hydrocarbons and certain individual PAHs (Cardellicchio et al. 2007; Liu et al. 2009; Bejarano and Michel 2010; Neser et al. 2012). For soils on land, there are certain recommendations related to the sum of the 16 most important PAHs. In Sweden, the maximum recommended concentration in soil for "sensitive human activities," for example gardening and cultivation of crops for human consumption, is $3 \mathrm{mg} \mathrm{kg}^{-1}$ and for "other" human activities, for example housing, is $20 \mathrm{mg} \mathrm{kg}^{-1}$ for medium weight PAHs (SNV 2008). Compared to these concentrations most levels found in this investigation in Eleme and Gokhana are high and restrictions would be recommended, depending on the activity.

From a toxicological standpoint, it is generally considered that acute biological effects of oil in sediments start to occur among the more sensitive organisms at levels in the $50-100 \mathrm{mg} \mathrm{kg}^{-1}$ (dry weight) range (NRC 2003). More resistant organisms (such as certain polychaete worms) can tolerate PAH concentrations in the range of several hundred $\mathrm{mg} \mathrm{kg}^{-1}$ (Forbes et al. 2001; Dean 2008).

\section{Petroleum Hydrocarbons in Biota}

The concentrations of EPHs in the tissues of fish and shellfish show an uneven picture of contamination of some of the samples, mainly in the form of the fractions C16C35 of the total aliphatics and aromatics. Out of the total of 88 samples of fish and shellfish analyzed, less than $10 \%$ showed measurable concentrations of EPH. The quantification limit was usually around $5 \mathrm{mg} \mathrm{kg}^{-1}$ and concentrations found in the samples were up to $161 \mathrm{mg} \mathrm{kg}^{-1}$ wet weight (UNEP 2011). Measurements of concentrations of PAHs in mussels and oysters from polluted coastal areas often show concentrations in the range of $10-100 \mathrm{mg} \mathrm{kg}^{-1}$ wet weight or $50-500 \mathrm{mg} \mathrm{kg}^{-1}$ dry weight (NRC 2003). Tissue from oysters in Lebanon after an oil spill measured 14-67 mg kg ${ }^{-1}$ (Lindén and Rust 2008). Oysters from Acajutla (El Salvador) were analyzed for PAHs and the result showed that most of the samples were at background concentrations, with the exception of samples from very close to an industrial site where higher concentrations were found (Michel and Zengel 1998). It has been reported that fish tend to avoid oil contaminated waters (Blaxter and Hallers-Tjabbes 1992). Observations at fish markets in the contaminated areas indicated that fish were present and traded, although most of the fish available were juveniles or sub-adults. Interviews with fishermen and fish trades indicated that fish catches in general had become very small and that it was now possible only to catch very few species of fishes. The small sizes of fish and the small catch figures could indicate that both overfishing and pollution are playing a role. No shellfish were found in the most impacted areas and the fishermen avoided these areas as well, as in their opinion there were less fish there and the oil would contaminate their fishing gear.

In fresh fish and seafood, the concentrations were below the quantification limit for most of the different PAHs in this investigation. In a few cases, measurable but low levels were found. Fish are able to metabolize petroleum hydrocarbons including PAHs to a varying degree and do not readily retain such compounds in the muscles (van der Oost 
et al. 2003; Reynaud and Deschaux 2006). Following the Prestige oil spill, the concentration of PAHs in oysters was found to be in the range of $0.3-1.4 \mathrm{mg} \mathrm{kg}^{-1}$ (Cortazar et al. 2008). Mussels from cultures in the North Sea show concentrations of $0.05-1 \mathrm{mg} \mathrm{kg}^{-1}$ and up to $4 \mathrm{mg} \mathrm{kg}^{-1}$ near an aluminum smelter in Scotland (McIntosh et al. 2004). In Laguna de Terminos (Mexico) in connection with an oil spill $2.5-42.5 \mathrm{mg} \mathrm{kg}^{-1}$ were analyzed in oysters (NoreñaBarroso et al. 1999). In Galveston Bay, Texas, the concentrations were up to $9.2 \mathrm{mg} \mathrm{kg}^{-1}$ in oysters (Qian et al. 2001). A survey of the concentrations in mussels from the western Mediterranean coast (Spain, France, Italy, Tunisia, Algeria, and Morocco) indicated total PAH levels up to $0.106 \mathrm{mg} \mathrm{kg}^{-1}$ dry weight (Galgani et al. 2010).

The investigation of the pollution levels in the aquatic environment in Ogoniland focused on the concentrations of EPHs and PAHs in surface waters, drinking water from wells, sediments, and biota. The results of the analyses indicated that the oil contamination was substantial in the study area. This contamination was visible in the form of slicks of oil and sheens covering extensive areas of mangrove fringed creeks and rivers of Gokhana, Eleme, Tai, and Khana LGAs. Surface waters, drinking water wells, and riverbed sediments were contaminated, sometimes to very high levels. The concentrations found in river waters and sediments were high enough to cause impacts to organisms, habitats, and entire ecosystems. Extensive areas of dead mangrove forests obviously killed by oil exposure illustrated the magnitude of impacts in the area. It was disturbing that very little recovery seems to be underway, probably because of high levels of oil in the sediment in these swamps. The levels of contamination also present a substantial human health and safety risk, particularly for a region where human activities and needs are closely tied to the environment. As an example, the very high concentrations of petroleum hydrocarbons found in drinking water wells should be a matter of great health concern for the local populations. The concentrations were over ten thousand times the national standard values for petroleum hydrocarbons in drinking water. Of major concern were also the high concentrations of benzene in some of the drinking water wells, up to nearly a thousand times the WHO guideline value. The concentrations of petroleum hydrocarbons found in fish were generally low. Furthermore, the investigations showed that relatively low levels of petroleum hydrocarbons were found in bivalves in $\mathrm{Og}$ oniland. No oysters were found in the highly impacted areas, probably due to the persistent oil contamination here.

The contamination of oil in large parts of Ogoniland is significant, particularly in Gokhana LGA where fresh oil could be seen drifting on surfaces as a film or sheen almost everywhere. However, extensive spills are common and have occurred throughout Ogoniland. Evidence of this is the widespread areas of dead mangrove vegetation covered with asphalt tar. A further indication that the contamination has a very long history is that in many places the mangrove consists of only dead trunks and thicker branches, while all the thinner branches and twigs have been lost over time due to various degradation processes (Fig. 9). This study was not carried out with the purpose of identifying the sources of the oil pollution in the area. Nevertheless, during the many days of field work in the Delta observations were made that indicate some of the sources. There is an illegal trade of stolen oil tapped from leaking pipelines and wellheads and from tankers offshore. This oil is transported through the delta in small boats and canoes on its way to small village refineries (Fig. 7). During the field survey the sampling teams observed oil being transported under very primitive conditions filled to the reeling in open boats and canoes through creeks and along rivers (Fig. 2). Spills from this type of transport are frequent. The sampling teams also observed extensive contamination of water and air in connection with artisanal refining (Fig. 7). Obviously, some oil spills also originate from aging and corroding pipelines and wellheads. The many parties involved in the conflict in the Delta naturally have various opinions as to who is to blame for the problems in the area and who is causing the oil contamination. Several news articles and a number of journalists who have or have not visited the area place the responsibility firmly on the oil companies and/or the government. However, according to Shell Nigeria, the largest producer of oil in the country, about $85 \%$ of the spills ( $95 \%$ by volume) is the result of sabotage, and the remaining portion is the result of operational activities (SPDC 2013). To be able to establish what is correct, impartial data based on factual evidence is needed. In this article, we have attempted to establish the degree of contamination as a baseline for the urgently required efforts to remediate and rehabilitate the damaged areas.

Table 5 Concentrations of PAHs in sediments from different ports around the world (Nemr et al. 2006)

\begin{tabular}{ll}
\hline Area & PAH $\left(\mathrm{mg} \mathrm{kg}^{-1}\right.$ dry weight $)$ \\
\hline Xiamen Harbour, China & $2.9-61$ \\
Saudi Arabia, Gulf & $11-6900$ \\
Kitimat Harbor, Canada & ND-10 000 \\
Lazaret Bay, France & $1.6-48.1$ \\
Gironde Estuary, France & $0.6-4.9$ \\
Crete, Greece & $0.5-5.7$ \\
Boston Harbor, USA & $7.3-358$ \\
Santander Bay, Spain & $0.02-25.8$ \\
Hsin-ta Harbor, Taiwan & $1.2-3.4$ \\
Red Sea & $0.16-10.5$ \\
\hline
\end{tabular}




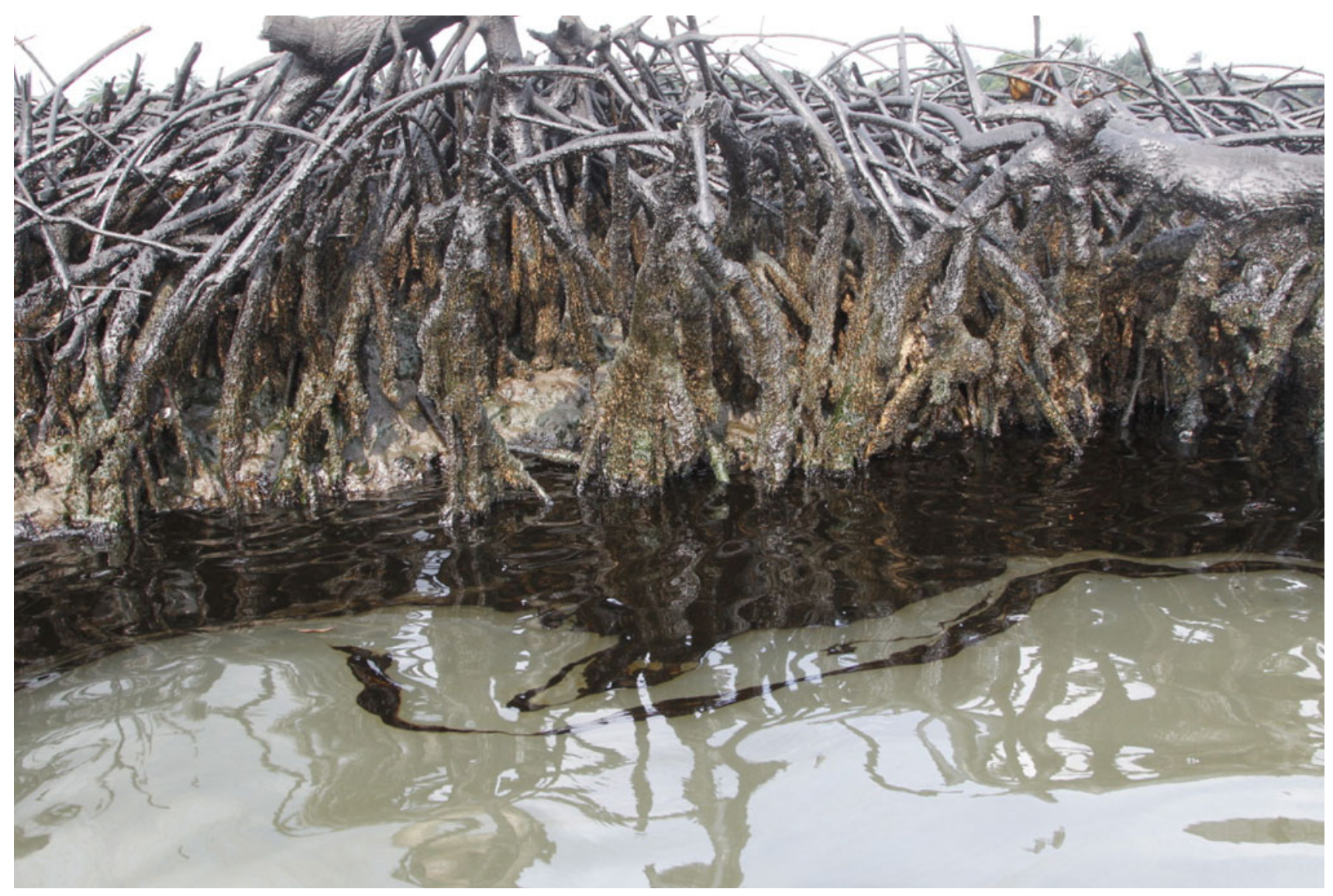

Fig. 9 Oil spills has caused extensive areas of dead mangrove vegetation in Gokhana, Ogoniland. Repeated oil spills have deposited asphalt tar on the remaining parts of the dead trees

\section{CONCLUSIONS}

This study is the first systematic investigation of the oil contamination in Ogoniland, Nigeria. It was part of a comprehensive UNEP-lead investigation to assess the environmental conditions in this part of the Niger Delta, where local opposition to the government and oil company operations have been particularly strong. The study showed extensive oil contamination of rivers, creeks, and ground waters. The oil originates from spills in connection with sabotage of oil infrastructures, spills in connection with transport of stolen oil, and leaks from aging and/or abandoned infrastructure. The spills have caused extensive damage to the mangroves, where large areas of the vegetation have died. The concentration of oil in streams and creeks was up to $7420 \mu \mathrm{g} \mathrm{L}^{-1}$, in sediments from the bottom of creeks, streams, and other water bodies up to $17900 \mathrm{mg} \mathrm{kg}^{-1}$. In drinking water wells, up to $42200 \mu \mathrm{g} \mathrm{L}^{-1}$ of petroleum hydrocarbons was found, about 14000 times the Nigerian standard for drinking water. Benzene concentrations were up to $9000 \mu \mathrm{g} \mathrm{L}{ }^{-1}$, more than 900 times the WHO guidelines. PAH concentrations in sediments reached $8.0 \mathrm{mg} \mathrm{kg}^{-1}$ in the most contaminated sites. Although the natural conditions for degradation of petroleum hydrocarbons are favorable with high temperatures and relatively high rainfall, the recovery of contaminated areas is prevented due to the chronic character of the contamination. This investigation has shown very extensive contamination of mangroves, creeks, and rivers, particularly in Gokhana. Even if the pollution were to stop, the fact that mangroves and wetland have been so heavily impacted indicates that a recovery of the affected areas is a matter of many years, perhaps decades.

Acknowledgments We wish to thank two anonymous reviewers for very good comments on the manuscript. A large number of people made this investigation possible. We wish to particularly acknowledge Dr. Muralee Thummarukudy, Mr. Michael J. Cowing, Dr. Babu Gopinathan, Mr. Thorsten Kallnischkies, Dr. Donna Vorhees, and Mr. Yves Barthelemy of the UNEP team and Dr. I.I. Kakulu Rivers State University of Science and Technology.

\section{REFERENCES}

Ana, G.R., M.K.C. Sridhar, and E.A. Bamgboye. 2009. Environmental risk factors and health outcomes in selected communities of the Niger delta area, Nigeria. Perspectives in Public Health 129: 183-191. 
Bejarano, A.C., and J. Michel. 2010. Large-scale risk assessment of polycyclic aromatic hydrocarbons in the shoreline sediments from Saudi Arabia: Environmental legacy after twelve years of the Gulf War oil spill. Environmental Pollution 158: 1561-1569.

Blaxter, J.H.S., and C.C.T. Hallers-Tjabbes. 1992. The effect of pollutants on sensory systems and behaviour of aquatic animals. Netherlands Journal of Aquatic Ecology 26: 43-58.

Bojes, H.K., and P.G. Pope. 2007. Characterization of EPA's 16 priority pollutant polycyclic aromatic hydrocarbons (PAHs) in tank bottom solids and associated contaminated soils at oil exploration and production sites in Texas. Regulatory Toxicology and Pharmacology 47: 288-295.

Bowyer, T., G.M. Blundell, M. Ben-David, S.C. Jewett, T.A. Dean, and L.K. Duffy. 2003. Effects of the Exxon Valdez oil spill on river otters: Injury and recovery of a sentinel species. Wildlife Monographs 153: 1-53.

Brakstad, O.G., and K. Bonaunet. 2006. Biodegradation of petroleum hydrocarbons in seawater at low temperatures $\left(0-5^{\circ} \mathrm{C}\right)$ and bacterial communities associated with degradation. Biodegradation 17: 71-82.

Cardellicchio, N., A. Buccolieri, S. Giandomenico, L. Lopez, and F. Pizzulli. 2007. Organic pollutants (PAHs, PCBs) in sediments from the Mar Piccolo in Taranto (Ionian Sea, Southern Italy). Marine Pollution Bulletin 55: 451-458.

Chan, H.T., and S. Baba. 2009. Manual on guidelines for rehabilitation of coastal forests damaged by natural hazards in the Asia-Pacific region. ISME \& ITTO.

CIA. 2012. World Factbook. In Nigeria. CIA, 1-15 https:// www.cia.gov/library/publications/the-world-factbook/geos/ countrytemplate_ni.html. Accessed 14 April 2012.

Cortazar, E., L. Bartolomé, S. Arrasate, A. Usobiaga, J.C. Raposo, O. Zuloaga, and N. Etxebarria. 2008. Distribution and bioaccumulation of PAHs in the UNESCO protected natural reserve of Urdaibai, Bay of Biscay. Chemosphere 72: 1467-1474. doi:10.1016/j.chemosphere.2008.05.006.

Dean, H.K. 2008. The use of polychaetes (Annelida) as indicator species of marine pollution: a review. Revista de Biología Tropical 56 4: 11-38.

EGASPIN. 2002. Environmental guidelines and standards for the petroleum industries in Nigeria (EGASPIN), 1992, revised 2002. Issued by the Department of Petroleum Resources, Nigeria.

EIR. 2005. The international crude oil market handbook, 2006. EIR, $1-696$.

Environment Agency, United Kingdom, 2002. The determination of polycyclic aromatic hydrocarbons in soil by dichloromethane extraction using gas chromatography with mass spectrometric detection. United Kingdom: Environment Agency.

Essien, J.P., S.I. Eduok, and A.A. Olajire. 2011. Distribution and ecotoxicological significance of polycyclic aromatic hydrocarbons in sediments from Iko River estuary mangrove ecosystem. Environmental Monitoring and Assessment 176: 99-107.

Forbes, V.E., M.S.H. Andreassen, and L. Christensen. 2001. Metabolism of the polycyclic aromatic hydrocarbon fluoranthene by the polychaete Capitella capitataspecies I. Environmental Toxicology and Chemistry 20: 1012-1021.

Frenken, K., and J.-M. Faurès. 1997. Irrigation potential in Africa: A basin approach. Food and agriculture organization of the United Nations. Land and water development division-Google Books. FAO.

Galgani, F., C. Martínez-Gómez, F. Giovanardi, G. Romanelli, J. Caixach, A. Cento, and A. Scarpato. 2010. Assessment of polycyclic aromatic hydrocarbon concentrations in mussels (Mytilus galloprovincialis) from the western basin of the Mediterranean Sea. Environmental Monitoring and Assessment 172: 301-317.

Gehle, K. 2009. Toxicity of polycyclic aromatic hydrocarbons (PAHs). Agency for toxic substances and disease registry ATSDR, 1-68.
Heubeck, M., K.C.J. Camphuysen, R. Bao, D. Humple, A. Sandoval Rey, B. Cadiou, and S. Bräger. 2003. Assessing the impact of major oil spills on seabird populations. Marine Pollution Bulletin 46: 900-902.

Human Rights Watch. 2005. Rivers and blood: Guns, oil and power in Nigerias Rivers State. A Human Rights Watch Briefing Paper.

Ibiebele, D.D. 1986. Point-source inputs of petroleum wastewater into the Niger Delta, Nigeria. Science of the Total Environment 52: 233-238.

Idemudia, U. 2009. The changing phases of the Niger Delta conflict: Implications for conflict escalation and the return of peace. Conflict. Report. SPDC. Port Harcourt.

IPIECA. 1991. Guidelines on biological impacts of oil pollution. International Petroleum Industry Environmental Conservation Association (IPECA).

ITOPF. 2011a. Effects of oil pollution on the marine environment. International Tankers Owners Pollution Federation (ITOPF).

ITOPF. 2011b. Fate of marine oil spills. International Tankers Owners Pollution Federation (ITOPF).

ITOPF. 2012. Sampling and monitoring of marine oil spills. International Tankers Owners Pollution Federation (ITOPF).

Jenssen, B.M. 1996. An overview of exposure to, and effects of, petroleum oil and organochlorine pollution in grey seals (Halichoerus grypus). Science of the Total Environment 186: 109-118.

Jinshu, Z., B.J. Richardson, O. Shouming, and Z. Jianhua. 2004. Distribution and sources of polycyclic aromatic hydrocarbon (PAH) in marine environment of China. Chinese Journal of Oceanology and Limnology 22: 136-145.

Juanes, J.A., A. Puente, J.A. Revilla, C. Álvarez, A. García, R. Medina, and S. Castanedo. 2007. The prestige oil spill in Cantabria (Bay of Biscay). Part II. Environmental assessment and monitoring of coastal ecosystems. Journal of Coastal Research 23: 978-992.

Kostka, J.E., O. Prakash, W.A. Overholt, S.J. Green, G. Freyer, A. Canion, and J. Delgardio. 2011. Hydrocarbon-degrading bacteria and the bacterial community response in Gulf of Mexico beach sands impacted by the Deepwater Horizon oil spill. Applied and Environmental Microbiology 77: 7962-7974.

Kvenvolden, K.A., and C.K. Cooper. 2003. Natural seepage of crude oil into the marine environment. Geo-Marine Letters 23: 140-146.

Lemieux, P.M., C.C. Lutes, and D.A. Santoianni. 2004. Emissions of organic air toxics from open burning: A comprehensive review. Progress in Energy and Combustion Science 30: 1-32.

Lerda, D. 2010. Polycyclic aromatic hydrocarbons (PAHs) factsheet. JRC Technical Notes, 1-32.

Lindén, O., and M. Rust. 2008. Oil spill damage to coastal ecosystems in Lebanon as a result of military action in July 2006. In Ocean yearbook 22, ed. A. Chircop, S. Coffen-Smout, and M. McConnell, 375-390. http://ioscproceedings.org/doi/pdf/10.7901/2169-33582008-1-339.

Liu, A., Y. Lang, L. Xue, and J. Liu. 2009. Ecological risk analysis of polyaromatic hydrocarbons (PAHs) in surface sediments from Laizhou Bay. Environmental Monitoring and Assessments 159: 429-436.

McIntosh, A.D., C.F. Moffat, G. Packer, and L. Webster. 2004. Polycyclic aromatic hydrocarbon (PAH) concentration and composition determined in farmed blue mussels (Mytilus edulis) in a sea loch pre- and post-closure of an aluminium smelter. Journal of Environmental Monitoring 6: 209.

Michel, J., and S. Zengel. 1998. Monitoring of oysters and sediments in Acajutla, El Salvador. Marine Pollution Bulletin 36: 256-266.

Middleditch, B.S. 1984. Ecological effects of produced water effluents from offshore oil and gas production platforms. Ocean management 9: 191-316. 
Mmom, P.C., and S.B. Arokoyu. 2010. Mangrove forest depletion, biodiversity loss and traditional resources management practices in the Niger Delta, Nigeria. Research Journal of Applied Sciences, Engineering and Technology 2: 28-34.

Moffat, D., and O. Linden. 1995. Perception and reality: Assessing priorities for sustainable development in the Niger River Delta. AMBIO 24: 527-538.

Mumtaz, M.M., J.D. George, K.W. Gold, W. Cibulas, and C.T. Derosa. 1996. Agency for toxic substances and disease registry, (ATSDR) evaluation of health effects of chemicals. IV. Polycyclic aromatic hydrocarbons (PAHs): Understanding a complex problem. Toxicology and Industrial Health 12: 742-995. http:// tih.sagepub.com/content/12/6/742.short.

Nemr, A.E., A. Khaled, A. El-Sikaily, T.O. Said, and A.M.A. AbdAllah. 2006. Distribution and sources of polycyclic aromatic hydrocarbons in surface sediments of the Suez Gulf. Environmental Monitoring and Assessment. doi:10.1007/s10661-0059009-4.

Neser, G., A. Kontas, D. Uensalan, O. Altay, and E. Darilmaz. 2012. Polycyclic aromatic and aliphatic hydrocarbon pollution at the coast of Aliaga (Turkey) ship recycling zone. Marine Pollution Bulletin 64: 1055-1059.

Nganje, T.N.T., A.E.A. Edet, and S.J.S. Ekwere. 2006. Distribution of $\mathrm{PAHs}$ in surface soils from petroleum handling facilities in Calabar. Environmental Monitoring and Assessment 130: 27-34.

Nielsen, T., H.E. Jørgensen, J.C. Larsen, and M. Poulsen. 1996. City air pollution of polycyclic aromatic hydrocarbons and other mutagens: Occurrence, sources and health effects. Science of the Total Environment 189-190: 41-49.

NOAA. 1994. Recovery of mangrove habitats at the Vesta Bella spill site. Hazmat Report, 1-37. National Oceanic and Atmospheric Administration (NOAA).

NOAA. 2002. Oil spills in mangroves: Planning and response considerations. Report, 1-72. National Oceanic and Atmospheric Administration (NOAA). http://archive.orr.noaa.gov/ book_shelf/34_mangrove_complete.pdf.

Noreña-Barroso, E., G. Gold-Bouchot, O. Zapata-Perez, and J.L. Sericano. 1999. Polynuclear aromatic hydrocarbons in American oysters Crassostrea virginica from the Terminos Lagoon, Campeche, Mexico. Marine Pollution Bulletin 38: 637-645.

NRC. 2003. Oil in the sea III: Inputs, fates, and effects. Washington, DC: National Academy Press.

Peterson, C.H., S.D. Rice, J.W. Short, D. Esler, J.L. Bodkin, B.E. Ballachey, and D.B. Irons. 2003. Long-term ecosystem response to the Exxon Valdez oil spill. Science 302: 2082-2086.

Qian, Y., T.L. Wade, and J.L. Sericano. 2001. Sources and bioavailability of polynuclear aromatic hydrocarbons in Galveston Bay, Texas. Estuaries and Coasts 24: 817-827.
Reynaud, S., and P. Deschaux. 2006. The effects of polycyclic aromatic hydrocarbons on the immune system of fish: A review. Aquatic Toxicology 77: 229-238.

Sauer, T.C., J.S. Brown, P.D. Boehm, D.V. Aurand, J. Michel, and M.O. Hayes. 1993. Hydrocarbon source identification and weathering characterization of intertidal and subtidal sediments along the Saudi Arabian coast after the Gulf War oil spill. Marine Pollution Bulletin 27: 117-134.

Singsaas, I., and A. Lewis. 2011. Behaviour of oil and other hazardous and noxious substances spilled in Arctic waters (BoHaSA). EPPR, 1-127. EPPR.

SNV. 2008. Tabell över generella riktvärden för förorenad mark, 1-3. Naturvårdsverket/Environmental Protection Agency, Stockholm, Sweden.

Soclo, H.H., P.H. Garrigues, and M. Ewald. 2000. Origin of polycyclic aromatic hydrocarbons (PAHs) in coastal marine sediments: Case studies in Cotonou (Benin) and Aquitaine (France) areas. Marine Pollution Bulletin 40: 387-396.

SPDC. 2013. Oil spills in the Niger Delta-Monthly data for 2012. http://www.shell.com.ng./environment-society/environment-tpkg/ oil-spills/data-2012.html. Accessed 5 March 2013.

UNEP. 2011. Environmental assessment of Ogoniland, 1-262. United National Environmental Programme (UNEP): Nairobi.

van der Oost, R., J. Beyer, and N.P.E. Vermeulen. 2003. Fish bioaccumulation and biomarkers in environmental risk assessment: A review. Environmental Toxicology and Pharmacology 13: 57-149.

WHO. 2003. Benzene in drinking water. Background document for development of WMO guidelines for drinking-water quality. WMO/SDE/WSH/03.04/24. World Health Organization.

\section{AUTHOR BIOGRAPHIES}

Olof Lindén $(\varangle) \mathrm{Ph} . \mathrm{D}$. is an expert in the environmental aspects of oil spills in different environments. He has been working with the Niger Delta and the environmental situation there since the 1990s. He is presently the Professor of Marine Environment Management at the World Maritime University in Malmö and he holds a professorship at the Linnaeus University in Kalmar, Sweden.

Address: World Maritime University, Malmö, Sweden.

Address: Linnaeus University, Kalmar, Sweden.

e-mail: ol@wmu.se

Jonas Pålsson is a research assistant at World Maritime University specializing in oil spill impacts in sensitive environments.

Address: Linnaeus University, Kalmar, Sweden. 